\title{
Stability is not enough: Preserving Business Sustainability of Cooperative through Market Diversification
}

\author{
Rizky Julianto Perkasa ${ }^{1}$, Ali Mutasowifin ${ }^{2}$ \\ \{rizky_21@apps.ipb.ac.id ${ }^{1}$, alimu@apps.ipb.ac.id $\left.{ }^{2}\right\}$ \\ Departement of Management, Faculty of Economic and Management, IPB University ${ }^{1,2}$
}

\begin{abstract}
Koperasi Peternak Sapi Bandung Utara (KPSBU) is a dairy breeding cooperative which produces dairy products. Up to now, around 93,35 percent of its products are delivered exclusively to several big dairy factories. This condition brings pressure to bear on KPSBU in terms of price and any other conditions. To enhance its autonomy, KPSBU needs strategies to use to develop its business. This study aims to analyze the internal-external factors that will affect the KPSBU business system and offer recommendations on strategies for business development. The data collection used in this study is Primary data which obtained by field observations and direct interviews with experts including the internal-external factors that influence the cooperative business; head of manager, production division, and processed milk. At the input stage, we use the internal-external matrix, matching stage with the SWOT analysis, and at the decision stage, we employ the Quantitative Strategy Planning Matrix. The results show that the priority strategies for KPSBU are by optimizing business process digitally (6.17), doing a partnership with the area of tourist attraction to be the supplier of dairy products (5.99), as well as providing training for a dairy cattle breeder in risk mitigation and livestock management $(5.84)$
\end{abstract}

Keywords: breeder, business strategy, cooperative, dairy, milk

\section{Introduction}

The rate of milk consumption in Indonesia is still categorized as very low, which is, around 16.5 liters per capita per year, That makes Indonesia is way behind compared to the other ASEAN countries, Malaysia (50.9 liter), Singapore (46.1 liter), Vietnam (20.1 liter) Not only in the consumption sector, in the production sector, around $79.08 \%$ of the milk supply inside the country is also imported, the national production only contributes around $20.92 \%$ to the supply of milk in the country [1]. The large amounts of imported milk make Indonesia depend on the country of milk producers. This phenomenon 
becomes a challenge for the local farmer to be able to fulfill the consumption of national milk.

The farmer business in Indonesia is still dominated by smallholder farms with average ownership of 1-3 breeders. The smallholder farms have these characteristics, which are, limited ownership of breeder, limited capital, and the management system is still traditional [2]. Therefore, the role of a cooperative cow breeder is needed to determine the position of the farmers' bargain in determining the amount of milk, the time of sales, and the price that is received by individual farmers with the purpose of the welfare of the members [3]. Some research mentioned that the role of the institution of cooperatives play an important role in improving production, quality of the product, to the welfare of conventional farmers [4].

Koperasi Peternak Sapi Bandung Utara (KPSBU) is one of the cooperatives engaged in the field of cow's dairy processing that exist in Indonesia. In 2018, the production's level of milk of KPSBU reached 133 tons per day by the number of members of as many as 7550 members and the population of cattle is up to 22000 . But in terms of the operation production, $K P S B U$ experienced a slope of $4.65 \%$ from the year earlier. The decreased productivity of the cows, the quality of food concentrate, and the handling of livestock, to the decreasing area of agricultural land, are the factor that affects cow's milk production.

In the business sector, Koperasi Peternak Sapi Bandung Utara (KPSBU) have their income from the selling of the milk by working together with several Industries of Milk's processing (IPS) such as PT Diamond Cold Storage and PT Frisian Flag Indonesia which is up to $74 \%, 16 \%$ for Sales of Concentrate Feed, 9\% for Waserda, and less than 1\% were processed into products processed milk.

The income of the farmers from the sales results of the milk, if $K P S B U$ sells their milk to IPS, is in the range of Rp $5000-6000$ depending on the quality of the milk received. It is not considered optimal when it is viewed from the ideal standard price that should be accepted. According to the Association of Cow Breeder in Indonesia (APSPI), the ideal price of cow's milk within the country is in the range of $\mathrm{Rp} 6500-7500$ per liter. The setting of an ideal price standard at the farmer level is able to lead to the fulfillment of the achievement of the national milk self-sufficiency target.

Cooperatives can improve the welfare of farmers to provide value-added to the products, because the price of milk as a commodity has been subject to increased volatility, diversification strategies have become increasingly important for dairy farms [5]. One example is to add the diversify the market by developing the diary products of $K P S B U$ branded as Freshtime to be 
marketed to consumers directly through official outlets. With the value-added to the processed product, the margin rates accepted by the farmers can increase up to Rp 7000 per liter of milk received.

\section{Literature Review \& Research Framework}

Cooperatives are institutions that grow on the basis of traditional solidarity and cooperation between individuals. A cooperative is a business entity with individual members or a cooperative legal entity based on its activities based on the cooperative principle as well as a people's economic movement based on the principle [6].

Strategy is defined as a plan with a large scale that is oriented towards the long term to achieve business goals. Strategic management decision-making process is fundamental, which aims to optimizing goals and objectives. A strategic-management process can be described as an objective, logical, systematic approach to make major decisions in an organization [7]. The data analysis process is divided into three working stages, they are input stage, matching stage, and decision stage.

1. At the input stage descriptive analysis is used, Internal Evaluation Factor (IFE) and External Factor Evaluation (EFE) matrix are used to evaluate the state of business and to explain the management conditions of $K P S B U$. The weight column must sum to 1.0 [8]. In contrast to the weights, the ratings show how well the firm is performing in regards to that factor, where a $4=$ the response is superior, $3=$ the response is above average, $2=$ the response is average, and $1=$ the response is below average.

2. The matching phase focuses on making alternative strategies by matching the internal and external factors using a SWOT (Strength-WeaknessOpportunities-Threats) analysis in the form of an Internal-External business entity matrix. SWOT analysis combines the strengths and weaknesses of an organization with the opportunities and threats that exist from the data collected [9].

3. The decision-making stage is carried out by analyzing the QSPM (Quantitative Strategy Planning Matrix) to determine the strategic decisions based on the weight of the IFE and EFE matrix. The QSPM method used to determine the attractiveness of factors built external and internal [7]. 


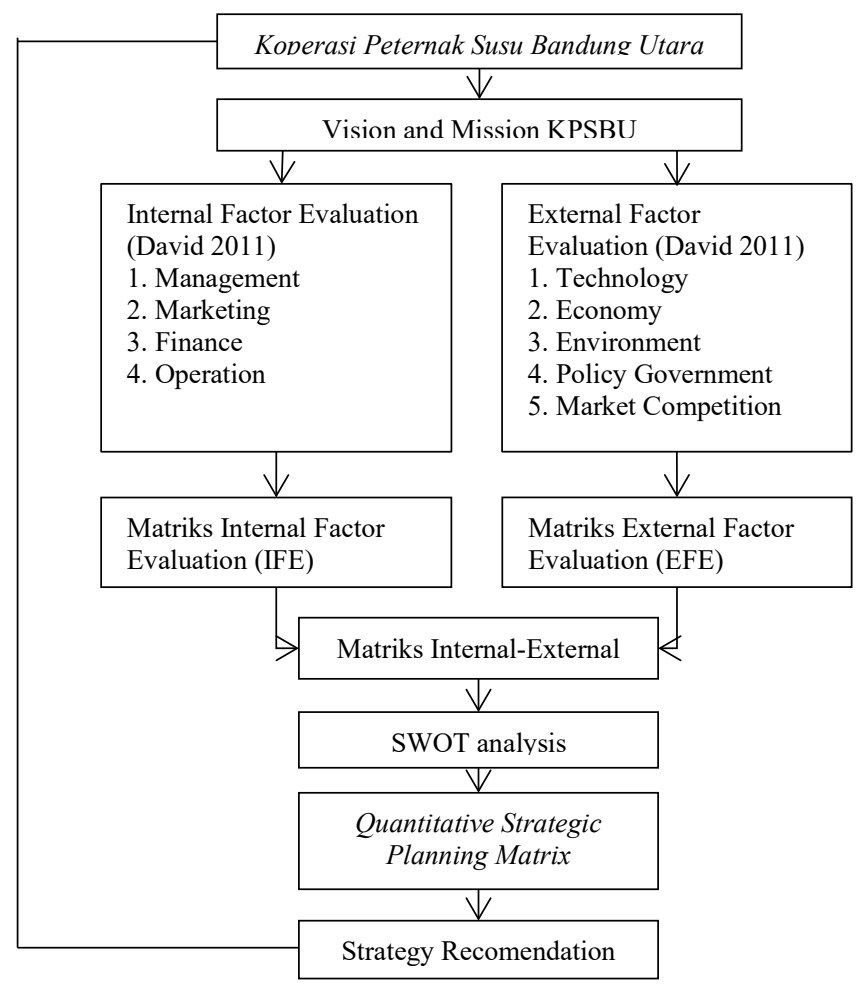

Fig. 1. Research Framework

Several studies use the business strategy case of internal-external factor evaluation performance to identify factors that influence business process in enterprises. Rumanti [10] examines the strategies based on strategic position analysis in small and medium enterprises. The research study with SPACE Matrix is used to map small medium enterprise into one of quadrants: aggressive, conservative, defensive, or competitive. And used QSPM for priorize the best strategy. Strategy approach by Erdil [11] has been developed to determine the strategy and criteria of a small-size enterprise in milk and the relationship between the dairy cattle farmers and firm performance with SWOT and AHP analytic. SWOT analysis will be implemented for a small scale enterprise in the food sector(milk factory) and alternative strategies will be determined that are based on SWOT factors. All of the factors are converted into a hierarchical structure. AHP model will be built and try to generate the general structure for enterprise.

A recent study was conducted by Hachouli [12] stated that strategy formulation to improve dairy milk performance in rural region in Switzerland. This research purpose is to concerning strategic management process which is strategy formulation, to survive and remain consistent to its goal, which is also 
automatically, can help to increase the revenue of agricultural dairy farms. From the data, two economic output variables were analysed as indicators for value added and labour productivity by the number of full-time equivalent (FTE) jobs on the farm. The result stated that it is necessary to provide a service that meets the demand from established tourism businesses. For planning stage, the research stated that entrepreneurial skills are needed in addition to a certain willingness to take risks.

Based on previous studies, it is known factor evaluation in each step and factors that affect the business process. After going through the stage of decision making, it produces the primary priority of the strategies. However, there are still different research results, so it is difficult to conclude how these multi-factors can affect business development.

The difference between this research and previous research is in the characteristic of the object research and the scope of the study. Research conducted an analysis on the object of cooperative research, which is oriented towards business development based on the welfare of members. This is different from corporations that focus on increasing profits. Business process analysis is carried out at KPSBU, with aspects of the scope of research consisting of business development regarding internal and external conditions of business institutions, including aspects of management, milk production, product marketing, and finance as internal factors as well as market competition, environmental conditions, technology, and the economy as external factors.

\section{Methodology}

\subsection{Data Collection}

The study was conducted at KPSBU located in Lembang, West Java, Indonesia. The information was collected at Head Office and KPSBU Milk Factory, when this research was conducted in January to March 2020.

The data collection used in this study is the primary and secondary data. Primary data is obtained by field observations and direct interviews with experts including the internal-external factors that influence the cooperative business processes; 1) head of manager, 2) head of production division, 3) Head of processed milk. Secondary data is obtained from annual business entity data reports, production and financial cooperative reports, literature studies through scientific journals, and relevant reports. 


\subsection{Method of Analysis}

The strategy business of cooperative can be known by breakdown each stage using three approaches of stages, there are input stage, matching stage, and decision stage with the details as follows.

Tabel 1. Type, Resource, Data Collection Method [7]

\begin{tabular}{|c|c|c|c|c|c|}
\hline No & Goals & $\begin{array}{l}\text { Type of } \\
\text { Data }\end{array}$ & $\begin{array}{l}\text { Data } \\
\text { Resource }\end{array}$ & $\begin{array}{l}\text { Data } \\
\text { Collection } \\
\text { Method }\end{array}$ & $\begin{array}{l}\text { Method of } \\
\text { Analysis }\end{array}$ \\
\hline 1. & $\begin{array}{l}\text { Identify factors } \\
\text { internal and } \\
\text { external strengths } \\
\text { and weaknesses } \\
\text { as well as the } \\
\text { opportunities and } \\
\text { threats of } K P S B U\end{array}$ & $\begin{array}{l}\text { Qualitative } \\
\text { Quantitative }\end{array}$ & $\begin{array}{l}\text { Primary } \\
\text { Secondary }\end{array}$ & $\begin{array}{l}\text { Literature } \\
\text { study, } \\
\text { Interview, } \\
\text { Weighting } \\
\text { Questionnaire }\end{array}$ & $\begin{array}{l}\text { IFE and } \\
\text { EFE Matrix }\end{array}$ \\
\hline 2 & $\begin{array}{l}\text { Formulate } \\
\text { alternatives } \\
\text { strategy ones } \\
\text { suitable for } \\
\text { developing the } \\
K P S B U \text { business } \\
\text { based on internal } \\
\text { and external } \\
\text { conditions }\end{array}$ & $\begin{array}{l}\text { Qualitative } \\
\text { Quantitative }\end{array}$ & Primary & $\begin{array}{l}\text { Interview, } \\
\text { Weighting } \\
\text { Questionnaire }\end{array}$ & $\begin{array}{l}\text { IE Matrix } \\
\text { SWOT } \\
\text { Matrix }\end{array}$ \\
\hline 3 & $\begin{array}{l}\text { Propose strategic } \\
\text { priorities for } \\
\text { developing the } \\
K P S B U \text { business }\end{array}$ & Quantitatie & Primary & $\begin{array}{l}\text { Weighting } \\
\text { Questionnaire }\end{array}$ & $\begin{array}{l}\text { Quantitative } \\
\text { Strategy } \\
\text { Planning } \\
\text { Matrix }\end{array}$ \\
\hline
\end{tabular}

The external and internal strategic factors conducted into IFE (Internal Factor Evaluation) and EFE (External Factor Evaluation) [13]. They showed how internal and external factors can be weighted and rated to illustrate how well management is responding to these specific factors rating in light of their perceived importance to the company weight for determine in the next stage of SWOT analysis.

SWOT (Strengths, Weaknesses, Opportunities and Threats) analysis, is a commonly used tool for analyzing internal and external environments in order to create a systematic approach and support for a decision situation [13]. 
Internal factor there are strength and weakness inside the company, amd external factors could be classified according to their attractiveness and success probability (opportunities) and probability of occurrence (threats).

The quantitative strategic planning matrix (QSPM) provides an analytical method for comparing feasible alternative actions [14]. The priority are selected for best strategy using input from other management techniques with some quantitative measurements. The sum of total attractiveness scores (STAS) is performed to find out the relative attractiveness of each key factor and its associated individual strategy.

\section{Discussion}

\subsection{The Object Study Characteristic}

Koperasi Peternak Sapi Bandung Utara (KPSBU) is one of the biggest milk cooperatives in Indonesia with an average milk production per day as much as 133 tons. $K P S B U$ shade individual breeders with the number of cattle around 22.000 and the members of $K P S B U$ recorded are around 7552 breeders at the end of 2018. In the effort of milk distribution, KPSBU distributed them by working together with PT Frisian Flag Indonesia and PT Diamond Cold Storage that hold the national milk stock, the detail can be seen in Figure 2.

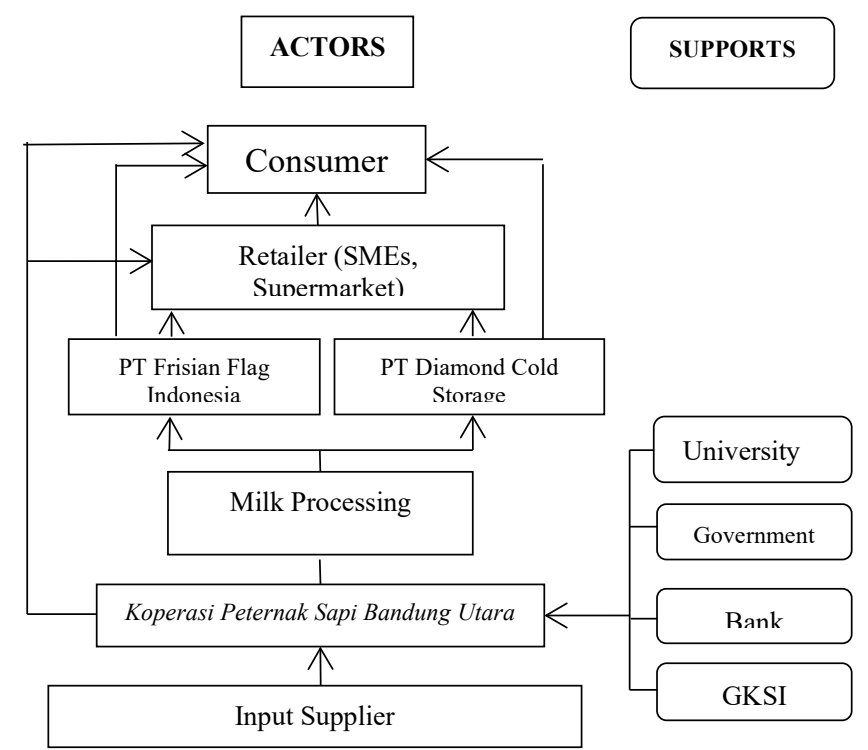

Fig. 2. SupplyChain of $K P S B U$ 
$K P S B U$ is a cooperative that processed in business and services. The line of business consists of marketing milk and Waserda. The services consist of livestock and financial services. Breeding services include animal health and insemination, concentrate feed, and cattle breeding. Financial services include member credit services for individual breeders. KPSBU has a vision "To become the leading dairy cooperative in Indonesia in the welfare of members". To achieve this vision KPSBU has a mission:1) Welfare of members through excellent service in the dairy industry with committed management; 2) Increase the institutional capacity of cooperatives through education, empowerment of human resources and strategic partnerships.

\subsection{Internal Factor Evaluation.}

The internal Factors used in this study are based on the condition of the business institution including the management, operation production, marketing, and financial [7]. Those key factors are analyzed with matrix Internal Factor Evaluation (IFE) to obtain the results of the weighting and rating on each factor key with the details as follows.

Table 2. KPSBU IFE Matrix

\begin{tabular}{|c|c|c|c|c|}
\hline \multirow[t]{2}{*}{ No } & Internal Strategy & \multirow[t]{2}{*}{ Weight } & \multirow[t]{2}{*}{ Rating } & \multirow{2}{*}{$\begin{array}{l}\text { EFI } \\
\text { Weight } \\
\text { Score }\end{array}$} \\
\hline & Strength $(\mathrm{S})$ & & & \\
\hline 1 & Structured management and supervision & 0.12 & 3.67 & 0.44 \\
\hline 2 & $\begin{array}{l}\text { Standardization of management quality and } \\
\text { procedures are well maintained }\end{array}$ & 0.14 & 4 & 0.56 \\
\hline 3 & Affordable price & 0.10 & 3.33 & 0.33 \\
\hline 4 & The high ability of milk production & 0.12 & 3.67 & 0.44 \\
\hline \multirow[t]{2}{*}{ No } & Internal Strategy & \multirow[t]{2}{*}{ Weight } & \multirow[t]{2}{*}{ Rating } & EFI \\
\hline & Weakness (W) & & & $\begin{array}{l}\text { Weight } \\
\text { Score }\end{array}$ \\
\hline 1 & $\begin{array}{l}\text { The lack of the store's branches of processed } \\
\text { product }\end{array}$ & 0.12 & 1.67 & 0.20 \\
\hline 2 & $\begin{array}{l}\text { The brand of the processed product } \\
\text { (Freshtime) is less known in the market }\end{array}$ & .15 & 2 & 0.30 \\
\hline 3 & $\begin{array}{l}\text { The choices of processed products is less } \\
\text { varied }\end{array}$ & 0.07 & 1.33 & 0.09 \\
\hline
\end{tabular}




\begin{tabular}{lllll}
\hline No & Internal Strategy & Weight & Rating & $\begin{array}{l}\text { EFI } \\
\text { Weight } \\
\text { Score }\end{array}$ \\
\cline { 2 - 3 } & Strength (S) & & 0.36 \\
\hline 4 & $\begin{array}{l}\text { The level of knowledge and skills of each } \\
\text { individual breeder suppliers is still relatively } \\
\text { low }\end{array}$ & & & \\
\hline Total & \multicolumn{2}{c}{1} & 2.72 \\
\hline
\end{tabular}

Quality of dairy product that is marketed either through the Milk Processing Industry or directly to consumers. This is evidenced by the existence of standard operational procedures carried out by $K P S B U$ management. the average milk quality at $K P S B U$ has reached the ideal production standard for the Indonesian National Milk Standards (SNI).

\subsection{External Factor Evaluation.}

The external environment is categorized as a factor of opportunity and threat. The chance factor can direct the organization activity, while the threat, can inhibit the movement of the organization. The key factor used in this research is the development of technology, the condition of the environment, the condition of the economy, the level of competition of the market, and the policy of the government. The results of interviews and weighting are arranged using the EFE matrix as follows.

Table 3. $K P S B U$ EFE Matrix

\begin{tabular}{llllll}
\hline No & External Strategy & Weight & Rating & $\begin{array}{l}\text { EFE } \\
\text { Weight } \\
\text { Score }\end{array}$ \\
\cline { 2 - 3 } & Opportunity (O) & & & \\
\hline 1 & $\begin{array}{l}\text { The government's response to the } \\
\text { development of the dairy farming } \\
\text { business is increasing }\end{array}$ & & 3.13 & 0.40 \\
\hline 2 & The large national milk market & 0.13 & 4 & 0.52 \\
\hline 3 & $\begin{array}{l}\text { The development of distribution and } \\
\text { storage technology }\end{array}$ & 0.14 & 3.67 & 0.51 \\
\hline 4 & $\begin{array}{l}\text { The tourism destination has a high traffic } \\
\text { of visitors }\end{array}$ & 0.10 & 3.33 & 0.33 \\
\hline
\end{tabular}




\begin{tabular}{lllll}
\hline No & Internal Strategy & Weight & Rating & $\begin{array}{l}\text { EFE } \\
\text { Weight } \\
\text { Score }\end{array}$ \\
\cline { 2 - 3 } Threats (T) & & 1 & 0.15 \\
\hline 1 & $\begin{array}{l}\text { The competitors with a more completed } \\
\text { product of dairy product ( local and } \\
\text { imported ) }\end{array}$ & 0.15 & 1.33 & 0.13 \\
\hline 2 & $\begin{array}{l}\text { Inflation rates that affect the operational } \\
\text { costs of a cattle farmer }\end{array}$ & 0.10 & 13 & 0.32 \\
\hline 3 & $\begin{array}{l}\text { Climatic conditions affect the livestock's } \\
\text { health and milk productivity. }\end{array}$ & 0.16 & 2 & 0.17 \\
\hline 4 & $\begin{array}{l}\text { There is a functional shift of land that } \\
\text { make the farmers face difficulty in } \\
\text { finding food }\end{array}$ & & 1.67 \\
\hline Total & 1 & & 2.53 \\
\hline
\end{tabular}

\subsection{Internal-External Matrix}

Based on the results obtained, the total score of the weighting of EFE $K P S B U$ is up to 2.53 and the total score of EFI is up to 2.72. Based on these results, then $K P S B U$ is located in quadrant $\mathrm{V}$.

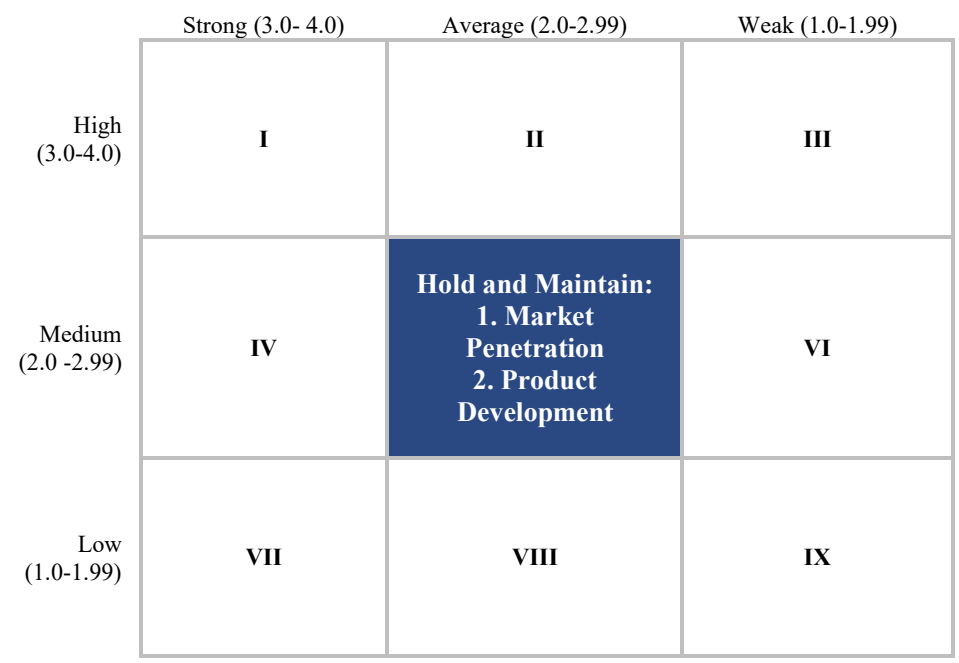

Fig. 3. $K P S B U$ Internal-External Matrix

Strategies that can be done in this condition is by doing market penetration, which is done by offering the product that already existed to the market with 
target expansion of the market area, along with product development, which is to develop and to improve the quality of the existed products.

\subsection{SWOT Matrix}

The factors used in SWOT consist of the factors on the EFE and EFI matrix [15]. The external factor of the business institution, namely chance, and threat, as well as internal factors, namely the strength and the weakness of business institutions, are matched until they produced various alternative strategies. The followings are the alternative of business strategies of KPSBU obtained from the result of the matching of the SWOT matrix.

Table 4. SWOT Matrix

\begin{tabular}{|c|c|c|}
\hline Internal Factor & Strength (S) & Weakness (W) \\
\hline External Factor & $\begin{array}{l}\text { 1. Structured } \\
\text { management system } \\
\text { 2. Standardization of the } \\
\text { management quality and } \\
\text { procedure are well } \\
\text { maintained } \\
\text { 3. Affordable price } \\
\text { 4. The high ability of } \\
\text { milk production }\end{array}$ & $\begin{array}{l}\text { 1. The lack of the store's } \\
\text { branches of processed } \\
\text { products } \\
\text { 2. The brand of the } \\
\text { processed product } \\
\text { (Freshtime) is less known } \\
\text { in the market } \\
\text { 3. The choices of the } \\
\text { products are less varied } \\
\text { 4. The level of knowledge } \\
\text { of individual breeder } \\
\text { suppliers is still relatively } \\
\text { low }\end{array}$ \\
\hline $\begin{array}{l}\text { Opportunity / } \\
\text { Opportunity (O) }\end{array}$ & SO Strategy & WO Strategy \\
\hline $\begin{array}{l}\text { 1. The government's } \\
\text { response to the } \\
\text { development of the } \\
\text { business of cow } \\
\text { breeder is quite high. } \\
2 \text {. The large national } \\
\text { demand for milk }\end{array}$ & $\begin{array}{l}\text { 1. Partnering with } \\
\text { tourism attraction to be } \\
\text { the supplier of dairy } \\
\text { products. ( } 1 \text {; } \mathrm{S} 2 ; \mathrm{S} 4 \text {; } \\
\mathrm{O} 2 ; \mathrm{O} 4) \\
\text { 2. Building marketing } \\
\text { outlets in potential areas }\end{array}$ & $\begin{array}{l}\text { 1. Digital optimization of } \\
\text { the process (W 2; W 5; } \\
\text { O2; O3) } \\
\text { 2. The role of the } \\
\text { government and } \\
\text { cooperative in making } \\
\text { policy to strengthen the }\end{array}$ \\
\hline
\end{tabular}




\begin{tabular}{|c|c|c|}
\hline $\begin{array}{l}\text { 3. The development of } \\
\text { distribution and } \\
\text { storage technology } \\
\text { 4. The tourism } \\
\text { destination has high } \\
\text { traffic of visitors. }\end{array}$ & $(\mathrm{S} 1 ; \mathrm{S} 2 ; \mathrm{S} 3 ; \mathrm{O} 2 ; \mathrm{O} 3)$ & $\begin{array}{l}\text { bargaining position of the } \\
\text { local farmers. (W 4; W 5; } \\
\text { O1) }\end{array}$ \\
\hline Threat / Threat (T) & ST Strategy & WT Strategy \\
\hline $\begin{array}{l}\text { 1. The high number of } \\
\text { competitors with more } \\
\text { complete dairy } \\
\text { products (local and } \\
\text { import) } \\
\text { 2. Inflation rates that } \\
\text { affect the operational } \\
\text { costs of cattle farmers } \\
\text { 3. The condition of the } \\
\text { weather and the } \\
\text { spread of disease in } \\
\text { animal livestock } \\
\text { 4. The functional shift } \\
\text { of land makes the } \\
\text { cattle face difficulty in } \\
\text { finding animal feed. }\end{array}$ & $\begin{array}{l}\text { 1. Developing the diary } \\
\text { products derived from } \\
\text { Freshtime (S 2; S 3; T1) }\end{array}$ & $\begin{array}{l}\text { 1. Conducting partnership } \\
\text { with the Government of } \\
\text { Bandung District in land } \\
\text { management (W 4; T 2; } \\
\text { T4) } \\
\text { 2. Providing training for a } \\
\text { dairy cattle breeder in risk } \\
\text { mitigation and livestock } \\
\text { management (W 4; T 2; } \\
\text { T3) }\end{array}$ \\
\hline
\end{tabular}

\section{S-O Strategy (Strength-Opprtunity).}

1. Partnering with tourism attraction to be the supplier of dairy products $K P S B U$ has an opportunity with its location to coincide in a tourist area with high traffic of visitors. It can be used to utilize the high milk production of $K P S B U$ by establishing a partnership with the tourism places to supply milk as a featured product of the area. The strategy is aimed to obtain marketing channels through collaboration with the tourism field which utilizes the location of Lembang as tourism attraction with the high traffic of visitors as a potential target market.

2 Building marketing outlets in potential areas

Penetration of the market by doing an expansion of marketing by offering old products and services to the new markets in potential regions outside Lembang using promotion or outlet as the distribution channel. With a good management structure and a guaranteed system of management quality, 
KSPBU is expected to be able to introduce and improve the processed product, Freshtime.

\section{W-O Strategy (Weakness-Opprtunity)}

1. Digital optimization of the business process

Steps to be taken by KPSBU can be done by doing digitization in the production and marketing sectors. With the development of technology in the digital age, KPSBU can take advantage of the strategy of a business institution to do digital marketing to reach consumers outside of Lembang. A large number of digital users in Indonesia make it an opportunity, remembering the large need for milk nationwide. From the production operation, the Enterprise Resource Planning (ERP) can increase the potential productivity of the operation. This system is still barely applied in Indonesia, especially in the cooperative industry.

2. Role of government policy

The condition of the milk trade in Indonesia is still dominated by imported products. The cooperation between the governments and the cooperative is expected to help strengthen the bargaining position of the local breeder from the threat of imported products by making policy to protect local products

\section{S-T Strategy (Strength-Threat)}

1. Conducting partnership with the government of Bandung District in land management.

The lack of land for farming becomes one of the threats where the functional shift of agriculture lands turning into residential and tourism attraction increasingly happened. A policy from the government in the region is needed to limit the reduction of land. With the policies that support the management of agriculture land, it will help the farmers to seek animal feed and maintaining the ecosystem.

\section{W-T Strategy (Weakness-Threat)}

1. Developing the dairy products of Freshtime

The Freshtime products sold by KPSBU are in the form of pure milk and yogurt. it is compared with the other competitors that have varied products such as cheese, skim milk powder, and more processed products. The innovative product and the quality of the product become an important key in this strategy

2. Providing training for a dairy cattle breeder in risk mitigation and livestock management

The strategy is to encourage $K P S B U$ to establish intensive communication and cooperation with the individual breeders and the other parties/agencies 
related. This aims to support training and assistance related to risk management in animal husbandry. Farm enterprises are a business that can't be separated from the risk of both internal and external risk. The board of $K P S B U$ can implement a strategy of periodic checking of the animals and developing the skills of the individual breeders to minimize the risks

\subsection{Quantitative Strategy Planning Matrix}

The decision-making stage is carried out by evaluating alternative categories of strategies that have been determined using the Quantitative Strategic Planning Matrix (QSPM). Based on the results of the QSPM calculation, several scores of Total Attractive Score (TAS) are acquired, the highest for each respective category strategy is as follows

Table 5. KPSBU Quantitative Strategy Planning Matrix

\begin{tabular}{|c|c|c|c|c|c|c|c|}
\hline \multirow{3}{*}{ Key factor } & \multicolumn{7}{|c|}{ Alternative Strategy } \\
\hline & \multirow[t]{2}{*}{ Weight } & \multicolumn{2}{|c|}{ Strategy 1} & \multicolumn{2}{|c|}{ Strategy 2} & \multicolumn{2}{|c|}{ Strategy 3} \\
\hline & & AS & TAS & AS & TAS & AS & TAS \\
\hline \multicolumn{8}{|l|}{ Strength } \\
\hline Structured management system & 0.12 & 4 & 0.48 & 4 & 0.48 & 4 & 0.48 \\
\hline $\begin{array}{l}\text { Standardization of the } \\
\text { management quality and } \\
\text { procedure are well maintained }\end{array}$ & 0.14 & 4 & 0.56 & 2 & 0.28 & 4 & 0.56 \\
\hline Affordable price & 0.10 & 3.67 & 0.37 & 3.33 & 0.33 & 3.67 & 0.37 \\
\hline $\begin{array}{l}\text { The high ability of milk } \\
\text { production }\end{array}$ & 0.12 & 3.33 & 0.40 & 4 & 0.48 & 4 & 0.48 \\
\hline \multicolumn{8}{|l|}{ Weakness } \\
\hline $\begin{array}{l}\text { The lack of the store's branches } \\
\text { of processed products }\end{array}$ & 0.12 & 2.33 & 0.28 & 1.33 & 0.16 & 1.33 & 0.16 \\
\hline $\begin{array}{l}\text { The brand of the processed } \\
\text { product (Freshtime) is less } \\
\text { known in the market. }\end{array}$ & 0.15 & 4 & 0.60 & 2.67 & 0.40 & 1.67 & 0.25 \\
\hline $\begin{array}{l}\text { The choices of the products are } \\
\text { less varied }\end{array}$ & 0.07 & 2.33 & 0.16 & 2 & 0.14 & 1.67 & 0.12 \\
\hline $\begin{array}{l}\text { The level of knowledge of } \\
\text { individual breeder suppliers is } \\
\text { still relatively low }\end{array}$ & 0.18 & 2 & 0.36 & 3.67 & 0.66 & 4 & 0.72 \\
\hline \multicolumn{8}{|l|}{ Opportunity } \\
\hline The government's response & 0.12 & 2.33 & 0.28 & 4 & 0.48 & 2 & 0.24 \\
\hline $\begin{array}{l}\text { The large national demand for } \\
\text { milk }\end{array}$ & 0.13 & 4 & 0.52 & 3.67 & 0.48 & 3.33 & 0.43 \\
\hline $\begin{array}{l}\text { The development of distribution } \\
\text { and storage technology }\end{array}$ & 0.14 & 4 & 0.56 & 2.67 & 0.37 & 2.33 & 0.33 \\
\hline $\begin{array}{l}\text { The tourism destination has high } \\
\text { traffic of visitors. }\end{array}$ & 0.10 & 2.33 & 0.23 & 2 & 0.20 & 1.33 & 0.13 \\
\hline \multicolumn{8}{|l|}{ Threat } \\
\hline $\begin{array}{l}\text { The high number of competitors } \\
\text { with more complete dairy } \\
\text { products (local and import) }\end{array}$ & 0.15 & 3.33 & 0.50 & 3.67 & 0.55 & 3 & 0.45 \\
\hline
\end{tabular}




\begin{tabular}{|c|c|c|c|c|c|c|c|}
\hline \multirow{3}{*}{ Key factor } & \multicolumn{7}{|c|}{ Alternative Strategy } \\
\hline & \multirow[t]{2}{*}{ Weight } & \multicolumn{2}{|c|}{ Strategy 1} & \multicolumn{2}{|c|}{ Strategy 2} & \multicolumn{2}{|c|}{ Strategy 3} \\
\hline & & AS & TAS & AS & TAS & AS & TAS \\
\hline $\begin{array}{l}\text { Inflation rates that affect the } \\
\text { operational costs of cattle } \\
\text { farmers }\end{array}$ & 0.10 & 2.67 & 0.27 & 3 & 0.30 & 3 & 0.30 \\
\hline $\begin{array}{l}\text { The condition of the weather } \\
\text { and the spread of disease in } \\
\text { animal livestock }\end{array}$ & 0.16 & 2 & 0.32 & 2 & 0.32 & 3.67 & 0.59 \\
\hline $\begin{array}{l}\text { The functional shift of land } \\
\text { makes the cattle face difficulty } \\
\text { in finding animal feed. }\end{array}$ & 0.10 & 2 & 0.20 & 3.33 & 0.33 & 2.67 & 0.27 \\
\hline TOTAL & & 48.32 & 6.09 & 47.34 & 5.96 & 45.67 & 5.87 \\
\hline
\end{tabular}

In the QSPM stage, the Total Attractive Score (TAS) is acquired from the seven alternative strategies. The strategy which becomes the first priority has the highest total average score value is the strategy to optimize the process of business in a digital way with total avarage score of 6.09 . The second priority is partnering with the area of tourist attraction to be the suppliers of milk products with total avarage score of 5.96; and the third priority is to provide training to farmers in risk mitigation and management of livestock with total avarage score 5.87 .

\section{Conclusion}

Based on the research and data processing, it can be concluded that in solving the problem to increase the effort of $K P S B U$ to achieve the welfare of $K P S B U$ members, they must understand the internal-external environment of the business institution. There are 8 indicators of internal factors and 8 external factors that affect the business institution. Internal factor covers management, production and operations, marketing, and finance. While, external factor covers the environment, economy, competitive markets, and policies of the government.

$K P S B U$ at the moment is in a position of hold and maintain with recommendation strategy of market penetration and product development. Based on the analysis of SWOT, strategy development that can be done is (1) partnering with the area of tourist attraction to be the supplier of dairy products. (2) building outlets marketing in potential areas, (3) digital optimization of business process, (4) the role of government and cooperative in making policy in order to strengthen the bargaining position of the local farmer against imported products, (5) doing a partnership with the government of Bandung District in land management, (6) developing the product of Freshtime, (7) providing training for a dairy cattle breeder in risk mitigation and livestock management 
After going through the stage of decision making, it produces the primary priority of the strategies, they are; the digital optimization of the business process (6:09), doing a partnership with the area of tourist attraction to be the suppliers of dairy products (5.96) and providing training for a dairy cattle breeder in risk mitigation and livestock management (5.87) The results of decision making analysis show that the weight of the quantitative strategy planning matrix is based on prioritize of each factor to maintain cooperative business process.

Therefore, to overcome the milk prices, which is the source of dairy coperative problems, it is necessary to maintain digital asset by improving the quality of its production operation. Digital optimization show that the efficiency and well-informed dairy farmer can affect a good impact for business process. However, the majority of cooperative production are still conservative, so it is essential to maintain the process digital production asset of cooperative. The results showed that doing partnership with the area of tourist attraction caused high weighting in QSPM, right location would be an opportunity for the company to expand the market. Cooperative also should to maintain their business by providing training for a dairy cattle breeder in risk mitigation and livestock management, that can mitigate business process losses of dairy milk.

This research cannot prove all the alternative strategy tested. Therefore, researchers then conduct further research in order to be able to analyze the effect of three priotize alternative stratgy that cannot be explained in this study or use another approach.

\section{References}

[1] Center for Agricultural Data and Information Systems. Agricultural Commodities in Animal Farm Subsector Outlook 2019. Avalilable at: Outlook Susu Sapi 2019 (pertanian.go.id)

[2] Susanty et al. 2018. Performance analysis and strategic planning of dairy supply chain in Indonesia: A comparative study. International Journal of Productivity and Performance Management, Vol. 67 No. 9, pp. 1435-1462. https://doi.org/10.1108/IJPPM-10-2017$\underline{0250}$

[3] Oktariani A. Daryanto A. Fahmi I. The Competitiveness Of Dairy Farmers Based Fresh Milkmarketing On Agro-Tourism. International Journal of Animal Health and Livestock Production Research. 2016. Vol.2, No.1, pp.18-38.

[4] Cardoso C.S., Keyserlingk M.A., Hotzel M.J. 2018. Views of Dairy Farmers, Agricultural Advisors, and Lay Citizens on the Ideal Dairy Farms. Journal of Dairy Science, Vol.102, no. 2. DOI= http://doi.org/10.3168/jds.2018-14688

[5] Mukson. Analysis of Determining Factors and Strategies in Dairy Cattle Agribusiness Improvement to Increase Milk Production in Central Java. The 5th International Seminar 
on Agribusiness 2019. 11 September 2019. Indonesia. 2019. IOP Conference Series: Earth and Environmental Science, Volume 518.

[6] Act of The Republic of Indonesia Number 25, 1992 concerning cooperative.

[7] David F. Strategic Management Concept and Case 13th Edition. New Jersey (US): Pearson Education Limited. 2011

[8] David M. David F. The Quantitative Strategic Planning Matrix Applied To A Retail Computer Store. 2009. The Coastal Business Journal. Vol 8, no.1.

[9] Rangkuti F. Analisis SWOT: Teknik Membedah Kasus Bisnis. Jakarta: Gramedia Pustaka Utama. 2000.

[10] Rumanti A, Syauta K. Determining Strategies Based on Strategic Position Analysis in Small and Medium Enterprises. International Journal of Information and Education Technology. 2013; Vol. 3, No. 4.

[11] Erdil A. Erbiyik H. Selection Strategy via Analytic Hierarchy Process: An Application for a Small Enterprise in Milk Sector. Journal Social and Behavioral Science. 2015; Volume 195: pp $2618-2628$.

[12] Hachouli A. Hochouli J. Schmid D. Competitiveness of Diversification Strategies in Agricultural Dairy Farms: Empirical Findings for Rural Region in Switzerland. Journal of Rural Studies. 2021. Vol. 98-106

[13] Kotler, P., 1988. Marketing Management: Analysis, Planning, Implementation, and Control, 6th edn, Prentice-Hall International Edition .

[14] Mallick S. Rudra S. Samantra R. Sustainable ecotourism development using SWOT and QSPMapproach: A study on Rameswaram, Tamil Nadu. International Journal of Geoheritage and Park. 2020. Vol. 8: pp 185-193.

[15] Kurttila M. Pesonen M. Kangas J. Kajanus M. Utilizing the analytic hierarchy process (AHP) in SWOT analysis - a hybrid method and its application to a forest-certification case. 2000. Journal Forest Policy and Economics, Volume 1 (2000): pp. 41-52 